\title{
KAJIAN TENTANG PENGATURAN SYARAT KEPAILITAN MENURUT UNDANG-UNDANG NOMOR 37 TAHUN 2004
}

\author{
Tata Wijayanta** \\ Bagian Hukum Acara, Fakultas Hukum Universitas Gadjah Mada, Yogyakarta \\ Jalan Sosio Yustisia Nomor 1, Bulaksumur, Sleman, D.I. Yogyakarta, 55281
}

\begin{abstract}
Article 2 paragraph (1) of the Act Number 37 of 2004 on Bankruptcy and Postponement of the Debt Payment Obligation does not stipulate the minimum amount of the debt for declaring a state of bankruptcy but only requires the existence of two debtors where one of the debts are found overdue. The Act that the only considerable condition has been "the unwillingness to pay the obligation" instead of the "incapability to pay" of the debtor. Also, the minimum amount of the debt must be determined in order to avoid another court decisions that awarded the request of bankruptcy whereas the debtor is actually capable to pay the obligation.
\end{abstract}

Keywords: bankruptcy, article 2 paragraph (1), conditions of bankruptcy.

\section{Intisari}

Pasal 2 ayat (1) Undang-Undang Nomor 37 Tahun 2004 tentang Kepailitan dan Penundaan Kewajiban Pembayaran Utang tidak mengatur minimal jumlah utang untuk mengajukan permohonan pailit. Untuk mengajukankepailitanhanyadiperlukandua orangkrediturdansalahsatuutangnyatidakdibayarpadawaktunya, sehingga hanya mendasarkan pada ketidakmauan (unwilling) dari si debitur dan bukan pada kemampuan (unable) debitur dalam membayar utang. Minimal jumlah utang ini perlu diatur sehingga kemudian tidak akan terjadi lagi putusan-putusan kepailitan terhadap debitur yang sebenarnya mampu dalam membayar utang.

Kata Kunci: kepailitan, Pasal 2 ayat (1), syarat kepailitan.

\section{Pokok Muatan}

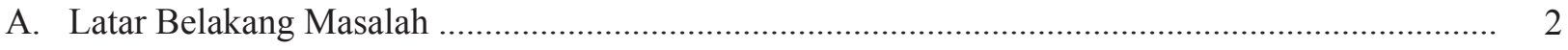

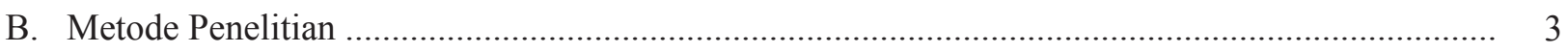

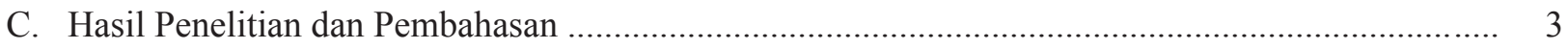

1. Ketentuan Pasal 2 ayat (1) tentang Syarat Kepailitan dalam Rancangan Undang-Undang Kepailitan dan Penundaan Kewajiban Pembayaran Utang (RUUKPKPU) dan

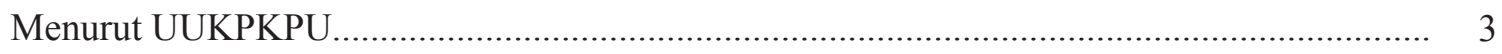

2. Tidak Diaturnya Minimal Jumlah Utang Dalam Pasal 2 Ayat (1) UUKPKPU.......................... 8

3. Perlu Diaturnya Minimal Jumlah Utang dalam Undang-Undang Kepailitan di Indonesia ........ 10

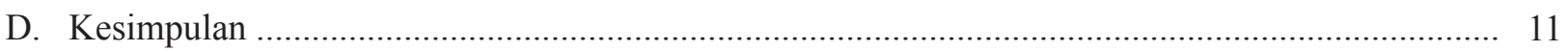

* Hasil Penelitian Fakultas Hukum Universitas Gadjah Mada Tahun 2013.
** Alamat korespondensi: tata_wijayanta@yahoo.com 


\section{A. Latar Belakang Masalah}

Di Indonesia sampai dengan saat ini pernah berlaku tiga peraturan perundang-undangan yang berkaitan dengan pengaturan kepailitan. Peraturan perundang-undangan yang pertama kali diberlakukan adalah peraturan perundangundangan produk jaman Belanda yaitu Staatsblad (Stb) 1905 Nomor 217 juncto 1906 Nomor 348 tentang Verordening op de Faillissement en Surceance van Betaling (Faillisement Verordening) (Peraturan Kepailitan). Peraturan perundangundangan ini kemudian dicabut berlakunya dengan diundangkannya Undang-Undang Nomor 4 Tahun 1998 tentang Perpu Nomor 1 Tahun 1998 tentang Kepailitan menjadi Undang-Undang (UUK) dan Undang-Undang yang terakhir ini kemudian juga direvisi dan dicabut dengan diundangkannya Undang-Undang Nomor 37 Tahun 2004 tentang Kepailitan dan Penundaan Kewajiban Pembayaran Utang (UUKPKPU).

Pencabutan berlakunya Peraturan Kepailitan berlatarbelakang terjadinya krisis ekonomi di sebagian besar negara Asia, ${ }^{1}$ termasuk juga yang dialami oleh Indonesia pada waktu itu. ${ }^{2}$ Data statistik perkara kepailitan setelah terjadinya krisis menunjukkan pertambahan jumlah yang signifikan. Data di pengadilan niaga misalnya menunjukkan bahwa pada tahun 1999 terdapat sejumlah 100 (seratus) perkara diperiksa dan diputus oleh pengadilan, 89 (delapan puluh sembilan) perkara diperiksa dan diputus (2000), diikuti oleh 66 (enam puluh enam) perkara diperiksa dan diputus (2001), ${ }^{3}$ 38 (tiga puluh delapan) perkara diperiksa dan diputus (2002), 14 (empat belas) perkara diperiksa dan diputus (sampai dengan November 2003) oleh pengadilan. ${ }^{4}$

Sampai dengan tahun 2003 tersebut, terdapat putusan perkara kepailitan yang sangat menarik dan menimbulkan persoalan terhadap eksistensi Undang-Undang Kepailitan yang berlaku pada saat itu, ${ }^{5}$ khususnya berkaitan dengan ketentuan mengenai syarat kepailitan. Putusan Pengadilan Niaga Jakarta Pusat Nomor 10/Pailit/2002/ PN.Niaga.Jkt.Pst dalam Perkara antara Paul Sukran, S.H. melawan PT Asuransi Jiwa Manulife Indonesia (AJMI) dalam putusannya memutuskan pailit PT Asuransi Jiwa Manulife Indonesia (AJMI) dan diikuti dengan putusan-putusan setelah itu yang menimbulkan persoalan tentang sangat sederhananya persyaratan penjatuhan pailit berdasarkan undang-undang kepailitan di Indonesia. ${ }^{6}$ Putusan-putusan yang dimaksud adalah Putusan Pengadilan Niaga Jakarta Pusat Nomor 13/ Pailit/2004/PN.Niaga.Jkt.Pst dalam Perkara Lee Boon Siong melawan PT Prudential Life Assurance, yang memailitkan PT Prudential Life Assurance

Terjadinya krisis moneter pada pertengahan 1997 berakibat terpengaruhnya mata uang, bursa saham dan harga aset lainnya di beberapa negara Asia yang dimulai di Thailand. Negara ini bersama dengan Korea Selatan dan Indonesia merupakan negara yang paling terkena dampak buruk krisis ekonomi. Hong Kong, Laos, Malaysia dan Filipina juga terpengaruh krisis tersebut tetapi akibat yang terjadi tidak separah seperti yang terjadi di Indonesia, Korea Selatan dan Thailand. Sementara itu, Republik Rakyat Cina, Taiwan, India, Vietnam, Brunei Darusalam, sedangkan Singapura hampir tidak terpengaruh dengan krisis ekonomi ini, sementara Jepang tidak terpengaruh banyak tapi mengalami kesulitan ekonomi jangka panjang. Lihat juga Bhagwam Chowdhry dan Amit Goyal, "Understanding The Financial Crisis in Asia", http://www.elsevier.com/ locateleconbase, diakses 20 April 2008.

Di Indonesia, krisis ekonomi telah memperburuk perekonomian negara. Lihat Bambang Kesowo, "Perpu Nomor 1 Tahun 1998 , Latar Belakang dan Arahnya", dalam A. Rudhy Lontoh, Denny Kailimang \& Benny Ponto [Ed.], 2001, Penyelesaian Utang Piutang Melalui Pailit atau Penundaan Kewajiban Pembayaran Utang, Alumni, Bandung, hlm. 99. Krisis ekonomi tersebut mengakibatkan turunnya nilai tukaran rupiah terhadap dollar Amerika Serikat dari 2.400.00 Rupiah (Rp) per 1 United State Dollar (USD) ke angka Rp 15.000.00 per 1USD pada waktu itu. Lihat Simon Johson, Peter Boone, Alasdair Breach, Eric Friedman, "Corporate Governance in the Asian Financial Crisis", Journal of Financial Economic, Vol. 58, No. 152. Rahmi Jened, "Perlindungan Hukum Investor Pemegang Obligasi dalam Rangka Perjanjian Perwaliamanatan Bank di Pasar Modal", http://www.library@lib.unair.ac.id, diakses 15 September 2004. Demikian juga, pada waktu krisis berlangsung jumlah perusahaan dan individu yang tidak mampu membayar utang bertambah jumlahnya. Ratusan bank dan ribuan debitor diambilalih manajemennya oleh pemerintah melalui Badan Penyehatan Perbankan Nasional (BPPN). Lihat S. Radelet dan J. Sachs, The Asset of the Asian Crisis, dalam Frederic S. Mishkin, "Lessons from the Asian Crisis", Journal of International Money and Finance, Vol. 18, No. 714. Sejumlah 398 perusahaan yang diantaranya adalah Badan Usaha Milik Negara (BUMN) yang tidak efisien dan selalu diproteksi oleh pemerintah jatuh dalam kondisi pailit yang mengakibatkan jumlah pengangguran di Indonesia mencapai 40 juta orang. Lihat Todd Mitton, "A Cross-Firm Analysis of the Impact of Corporate Governance on the East Asian Financial Crisis", Journal of Financial Economic, Vol. 64, No. 215.

Elisabeth Nurhaini Butar-Butar, 2001, Relevansi Pengadilan Negeri/Niaga dalam Menyelesaikan Utang Piutang, Tesis, Program Pascasarjana Fakultas Hukum Universitas Gadjah Mada, Yogyakarta, hlm. 11.

Tata Wijayanta, 2003, Relevansi Lembaga Dissenting Opinion dalam Penyelesaian Sengketa Kepailitan di Pengadilan Niaga,

Tesis, Program Pascasarjana Fakultas Hukum Universitas Gadjah Mada, Yogyakarta, hlm. 93.

Undang-Undang yang dimaksud disini adalah Undang-Undang Nomor 4 Tahun 1998 tentang Kepailitan (Lembaran Negara Republik Indonesia Tahun 1998 Nomor 7).

Undang-Undang yang dimaksud disini adalah Undang-Undang Nomor 37 Tahun 2004 tentang Kepailitan dan Penundaan Kewajiban Pembayaran Utang (Lembaran Negara Republik Indonesia Tahun 2004 Nomor 131). 
dan dipailitkannnya perkara PT Telekomunikasi Seluler dalam Putusan Pengadilan Niaga Jakarta Pusat Nomor 48/Pailit/2012/PN.Niaga.JKT.PST.

Syarat kepailitan berdasarkan ketentuan Pasal 2 ayat (1) UUKPKPU menyebutkan bahwa debitor yang mempunyai dua atau lebih kreditor dan tidak membayar lunas sedikitnya satu utang yang telah jatuh waktu dan dapat ditagih, dinyatakan pailit dengan putusan pengadilan, baik atas permohonannya sendiri maupun atas permohonan satu atau lebih kreditornya.

Berdasarkan ketentuan tersebut dapat disimpulkan adanya 3 (tiga) syarat untuk dapat dipailitkan, yaitu: (1) harus ada utang; (2) salah satu dari utang telah cukup waktu dan dapat ditagih; dan

(3) debitur mempunyai sekurang-kurangnya dua atau lebih kreditur. Syarat kepailitan sebagaimana yang diatur dalam Pasal 2 ayat (1) UUKPKPU ini memang sangat sederhana. Debitor dengan kemampuan membayar utang dapat dipailitkan oleh pengadilan ketika ketiga syarat kepailitan secara normatif terpenuhi.

Berdasarkan latar belakang sebagaimana diuraikan di atas, permasalahan yang diteliti adalah: Pertama, mengapa ketentuan Pasal 2 ayat (1) UUKPKPU merumuskan syarat kepailitan sangat sederhana yaitu debitor yang mempunyai dua atau lebih kreditor dan tidak membayar lunas sedikitnya satu utang yang telah jatuh waktu dan dapat ditagih?; Kedua, mengapa ketentuan Pasal 2 ayat (1) UUKPKPU tidak mengatur minimal jumlah utang sebagai syarat untuk mengajukan permohonan pailit?; dan Ketiga, apakah dalam perlu diatur tentang kemampuan debitor dalam membayar utang?

\section{B. Metode Penelitian}

Penelitian ini adalah penelitian hukum normatif yang menggunakan data sekunder dengan melakukan penelitian kepustakaan. ${ }^{7}$ Data sekunder bersumber dari bahan hukum primer, sekunder dan tersier dan diperoleh melalui dokumen-dokumen, peraturan perundang-undangan, putusan pengadilan dan tulisan-tulisan lain yang berhubungan dengan topik penelitian. Oleh karena penelitian ini terutama dimaksudkan untuk mengkaji dan menganalisis ketentuan Pasal 2 ayat (1) UUKPKPU tentang syarat kepailitan maka data sekunder yang paling utama adalah dokumen Pembahasan RUUKPKPU dan Risalah Rapat Paripurna DPR RI dalam Pembicaraan Tingkat II/Pengambilan Keputusan terhadap RUUKPKPU. Cara pengumpulan data dilakukan dengan metode dokumentasi, yaitu merujuk/mengumpulkan pada bahan-bahan yang didokumentasikan, ${ }^{8}$ sedangkan alat pengumpul data yang digunakan adalah studi dokumen, yaitu studi dengan cara mempelajari/mengkaji dokumen-dokumen baik berupa dokumen Pembahasan RUUKPKPU dan Risalah Rapat Paripurna DPR RI dalam Pembicaraan Tingkat II/Pengambilan Keputusan Terhadap RUUKPKPU, buku, laporan hasil penelitian, makalah seminar, tulisan para ahli, putusan-putusan pengadilan dan semua peraturan yang berkaitan dengan materi penelitian. Data yang diperoleh dianalisis dengan menggunakan content analysis (analisis isi), ${ }^{9}$ dan comparation analysis (analisis komparasi/perbandingan).

\section{Hasil Penelitian dan Pembahasan \\ 1. Ketentuan Pasal 2 ayat (1) tentang Syarat Kepailitan dalam Rancangan Undang-Undang Kepailitan dan Penundaan Kewajiban Pembayaran Utang (RUUKPKPU) dan Menurut UUKPKPU}

Naskah RUUKPKPU disampaikan Pemerintah dengan Surat Presiden Republik Indonesia Nomor: R.03/PU/V/2002 tanggal 13 Mei 2002, perihal: Pengantar RUUKPKPU kepada Pimpinan Dewan Perwakilan Rakyat Republik Indonesia (DPR RI). Beberapa materi atau substansi baru dalam RUUKPKPU misalnya: (a) judul RUU; (b) pihak yang berhak mengajukan pailit dan PKPU; (c) prosedur pengajuan permohonan Pailit; (d)

Ronny Hanitijo Soemitro, 1994, Metodologi Penelitian Hukum dan Jurimetri, Ghalia Indonesia, Jakarta, hlm. 52.

Ranjit Kumar, 1999, Research Methodology: A Step-by-Step Guide for Beginners, Addison Wedley Longman Australia Pty. Limited,

Melbourne, hlm. 104.

Earl Babbie, 1986, The Practice of Social Research, Wadsworth Publishing Co., California, hlm. 204. 
hal-hal yang berkaitan dengan pengadilan niaga; (e) permohonan peninjauan kembali; (f) ketentuan lain, ketentuan peralihan dan ketentuan penutup.

Judul RUU yaitu tentang "Kepailitan dan Penundaan Kewajiban Pembayaran Utang" sesuai dengan cakupan materi yang diatur yaitu mengenai kepailitan dan Penundaan Kewajiban Pembayaran Utang. Pihak yang berhak mengajukan permohonan pailit dan penundaan kewajiban pembayaran utang ditambah yakni: (a) bursa efek, lembaga kliring dan penjaminan dan lembaga penyimpanan dan penyelesaian, permohonan pernyataan pailit hanya dapat diajukan oleh Badan Pengawas Pasar Modal (Bapepam), karena lembaga tersebut melakukan kegiatan berhubungan dengan dana masyarakat yang diinvestasikan dalam efek atau saham di bawah pengawasan Bapepam; (2) perusahaan asuransi, perusahaan reasuransi atau dana pensiun permohonan pernyataan pailit hanya dapat diajukan oleh Menteri Keuangan. Ketentuan ini diperlukan untuk membangun tingkat kepercayaan masyarakat terhadap perusahaan asuransi atau perusahaan reasuransi sebagai lembaga pengelola resiko dan sekaligus sebagai lembaga pengelola dana masyarakat yang memiliki kedudukan strategis dalam pembangunan dan kehidupan perekonomian, sedangkan ketentuan mengenai dana pensiun, mengingat dana pensiun tersebut mengelola dana masyarakat dalam jumlah besar dan dana tersebut merupakan hak dari peserta yang banyak jumlahnya.

Prosedur pengajuan permohonan pailit ke pengadilan niaga oleh Bank Indonesia, Bapepam dan Menteri Keuangan ditentukan tidak perlu melalui jasa advokat, pengacara praktek atau penasehat hukum yang mempunyai izin praktek. Ketentuan tersebut atas dasar pertimbangan bahwa lembaga tersebut lebih mengetahui dan menguasai permasalahan pailit sesuai bidangnya, sedangkan permohonan pailit berkenaan dengan kepentingan umum tetap dilakukan oleh jaksa. Ketentuan mengenai kepentingan umum dalam arti kepentingan bangsa dan negara dan atau kepentingan yang lebih luas, misalnya: (a) debitor melarikan diri; (b) debitor menggelapkan bagian dari harta kekayaan; (c) debitor mempunyai utang kepada Badan Usaha Milik Negara (BUMN) atau badan usaha lain yang menghimpun dana masyarakat; (d) debitor mempunyai utang yang berasal dari perhimpunan dana dari masyarakat luas; (e) debitor tidak beritikad baik atau tidak kooperatif dalam menyelesaikan masalah utang piutang yang telah jatuh waktu; atau (f) alam hal lainnya menurut kejaksaan merupakan kepentingan umum

Berkaitan dengan pengadilan niaga antara lain diaturnya tentang: (a) pemberian wewenang panitera untuk menolak permohonan pernyataan pailit bagi Bank Indonesia, Bapepam dan Menteri Keuangan yang diajukan oleh pihak lain selain Bank Indonesia, Bapepam dan Menteri Keuangan. Hal ini dimaksudkan untuk mencegah pihak lain mengajukan pailit terhadap lembaga-lembaga tersebut; (b) dissenting opinion yaitu dimuatnya perbedaan pendapat masing-masing anggota atau ketua majelis hakim dalam putusan pengadilan niaga. Hal ini dimaksudkan sebagai salah satu cara agar masyarakat dapat menilai pendapat anggota atau ketua majelis dalam mengambil putusan, disamping itu, untuk memotivasi para hakim pengadilan niaga dalam memberikan pendapat atau pertimbangan dalam mengambil putusan senantiasa didasarkan pada profesionalismenya; (c) kurator dalam menangani perkara kepailitan dan penundaan kewajiban pembayaran utang tidak boleh lebih dari tiga perkara. Hal ini dimaksudkan agar penyelesaian kepailitan dan penundaan kewajiban pembayaran utang yang ditangani oleh kurator dapat berjalan efektif, efisien dan mencegah kolusi dan nepotisme diantara para pihak yang terlibat dalam kepailitan dan penundaan kewajiban pembayaran utang seperti jual beli perkara; dan (d) zero hour rule yaitu ketentuan mengenai waktu kapan putusan pernyataan pailit diucapkan. Dalam RUU ini ditentukan dihitung mulai berlaku sejak pukul 00.00 WIB. Ketentuan tersebut dimaksudkan untuk menjamin kepastian hukum.

Kriteria permohonan Peninjauan Kembali dipertegas dengan kriteria sebagai berikut: (a) apabila terdapat surat bukti yang bersifat menentukan yang pada waktu perkara diperiksa di pengadilan sudah ada tetapi belum ditemukan dan; (b) diajukan apabila terdapat kekeliruan hakim dalam memberikan putusan. Ketentuan lain-lain mengatur mengenai keberadaan hakim ad hoc di Mahkamah Agung 
dan berwenangnya pengadilan niaga memeriksa sengketa utang piutang antara debitor dan kreditor yang terikat dengan perjanjian arbitrase. Ketentuan peralihan mengatur mengenai perkara yang telah diputus tetapi belum dilaksanakan atau yang belum diputus, diselesaikan berdasarkan ketentuan dalam Undang-Undang Kepailitan yang baru serta diatur pula mengenai tetap berlakunya peraturan pelaksanaan dari UUK sepanjang belum ada peraturan baru dan yang tidak bertentangan dengan UndangUndang yang baru, sedangkan ketentuan penutup memuat pencabutan Peraturan Kepailitan, Perpu Nomor 1 Tahun 1998 tentang Perubahan Atas Undang-Undang tentang Kepailitan yang kemudian ditetapkan menjadi UUK.

Sekiranya dicermati hal-hal baru tentang syarat kepailitan sebagaimana diatur dalam Pasal 2 RUUKPKPU tersebut salah satunya hanya menyempurnakan dengan menambah ketentuan tentang kewenangan Menteri Keuangan bagi permohonan pailit perusahaan asuransi, perusahaan reasuransi, dana pensiun ataupun Badan Usaha Milik Negara (BUMN) yang bidang usahanya berkaitan dengan kepentingan umum, sedangkan secara substansi, syarat kepailitan tidak ada perubahan sama sekali. Untuk dapat diajukan pailit secara materiil harus ada utang, minimal dua kreditur dan salah satunya tidak dilunasi pada waktu yang telah diperjanjikan. Penyempurnaan tentang syarat kepailitan sama sekali tidak menyentuh tentang batas minimum jumlah utang untuk dapat dipailitkan ke pengadilan, meskipun dalam praktek sebelumnya beberapa perusahaan yang mampu menjadi korban dari ketentuan tentang syarat kepailitan ini.

\section{a. Ketentuan Pasal 2 Ayat (1) RU UKP KPU Versi Pemerintah}

RUUKPKPU disampaikan oleh pihak pemerintah kepada Pimpinan Dewan Perwakilan Rakyat Republik Indonesia (DPR RI) melalui Surat Presiden Republik Indonesia Nomor: R.03/PU/V/2002 tanggal 13 Mei 2002, perihal Pengantar RUUKPKPU. Ketentuan Pasal 2 RUUKPKPU tentang syarat pailit dimaksudkan untuk menyempurnakan ketentuan tentang syarat kepailitan yang berlaku sebelumnya sebagaimana diatur dalam ketentuan Pasal 1 UUK. Ketentuan Pasal 1 UUK menyebutkan bahwa:

(1) Debitur yang mempunyai dua atau lebih kreditur dan tidak membayar sedikitnya satu utang yang telah jatuh waktu dan dapat ditagih, dinyatakan pailit dengan putusan.

(2) Pengadilan yang berwenang sebagaimana dimaksud dalam Pasal 2, baik atas permohonannya sendiri, maupun atas permintaan seorang atau lebih krediturnya.

(3) Permohonan sebagaimana dimaksud dalam ayat (1), dapat juga diajukan oleh Kejaksaan untuk kepentingan umum.

(4) Dalam hal menyangkut debitur yang merupakan bank, permohonan pernyataan pailit hanya dapat diajukan oleh Bank Indonesia.

(5) Dalam hal menyangkut debitur yang merupakan perusahaan efek, permohonan pernyataan pailithanya dapat diajukan oleh Badan Pengawas Pasar Modal.

Pasal 2 RUUKPKPU menyebutkan bahwa:

(1) Debitoryang mempunyaidua atau lebih kreditor dan tidak membayar lunas sedikitnya satu utang yang telah jatuh waktu dan dapat ditagih, dinyatakan pailit dengan putusan pengadilan yang berwewenang, baik atas permohonannya sendiri maupun atas permohonan satu atau lebih kreditornya.

(2) Permohonan sebagaimana dimaksud dalam ayat (1) dapat juga diajukan oleh kejaksaan untuk kepentingan umum

(3) Dalam hal debitor adalah bank, permohonan pernyataan pailit hanya dapat diajukan oleh Bank Indonesia.

(4) Dalam hal debitor adalah perusahaan efek, bursa efek, lembaga kliring dan penjaminan, lembaga penyimpanan dan penyelesaian, permohonan pernyataan pailit hanya dapat diajukan oleh Badan Pengawas Pasar Modal.

(5) Dalam hal debitor adalah perusahaan asuransi, perusahaan reasuransi atau Dana Pensiun, permohonan pernyataan pailit hanya dapat diajukan oleh Menteri keuangan.

Meskipun ketentuan Pasal 1 UUK 
tidak menyebutkan secara eksplisit tentang syarat kepailitan dalam ketentuan pasal tersebut, namun demikian syarat kepailitan secara implisit (tersurat) dapat disimpulkan dalam ketentuan Pasal 1 ayat (1) yang menyebutkan bahwa:

Debitur yang mempunyai dua atau lebih kreditur dan tidak membayar sedikitnya satu utang yang telah jatuh waktu dan dapat ditagih, dinyatakan pailit dengan putusan Pengadilan yang berwenang sebagaimana dimaksud dalam Pasal 2, baik atas permohonannya sendiri, maupun atas permintaan seorang atau lebih krediturnya.

Sementara Pasal 2 ayat (1) RUUKPKPU adalah salah satu ayat di dalam ketentuan Pasal 2 dan merupakan bagian dari judul bagian kesatu tentang putusan pailit dengan judul bab tentang kepailitan. Secara eksplisit Bagian kesatu mengatur tentang syarat dan putusan pailit. Syarat pailit sebagaimana diatur dalam ketentuan Pasal 2 ayat (1) menyebutkan bahwa:

Debitor yang mempunyai dua atau lebih kreditor dan tidak membayar lunas sedikitnya satu utang yang telah jatuh waktu dan dapat ditagih, dinyatakan pailit dengan putusan pengadilan yang berwewenang, baik atas permohonannya sendiri maupun atas permohonan satu atau lebih kreditornya.

Sekiranya disandingkan tentang syarat kepailitan antara Pasal 1 ayat (1) UUK dengan Pasal 2 ayat (1) RUUKPKPU maka dapat disimpulkan bahwa kedua ketentuan tersebut mengatur hal yang sama dan secara substansial tidak mengatur minimum jumlah utang untuk dapat diajukan permohonan pailit ke pengadilan. Syarat untuk dapat diajukan pailit yaitu adanya utang, Debitor yang mempunyai dua atau lebih kreditor dan tidak membayar lunas sedikitnya satu utang yang telah jatuh waktu dan dapat ditagih. Perubahan dan penyempurnaan Pasal 2 RUUKPKPU terhadap Pasal 1 UUK ini hanya berkaitan tentang syarat mengenai siapa yang mempunyai ke- wenangan untuk mengajukan permohonan pailit perusahaan asuransi, perusahaan reasuransi, dana pensiun ataupun Badan Usaha Milik Negara (BUMN) yang bidang usahanya berkaitan dengan kepentingan umum.

Berdasarkan naskah RUUKPKPU sebagaimana yang disampaikan oleh pihak pemerintah, isu tentang minimal jumlah utang untuk dapat dipailitkan belum dan bukan merupakan persoalan yang perlu diatur untuk merevisi ketentuan tentang syarat kepailitan sebagaimana diatur dalam UUK yang berlaku sebelumnya. Meskipun dalam praktek ketika berlakunya UUK beberapa perusahaan yang sebenarnya mampu membayar utang dipailitkan oleh pengadilan, seperti PT AJMI dan PT Asuransi Prudential Life.

\section{b. Pembahasan RUUKPKPU Khu- susnya Ketentuan Pasal 2 Ayat (1) di DPR RI}

RUUKPKPU yang disampaikan pemerintah ke DPR RI berdasarkan Surat Presiden Republik Indonesia Nomor: R.03/ $\mathrm{PU} / \mathrm{V} / 2002$ tanggal 13 Mei 2002, perihal Pengantar RUU tentang Kepailitan dan Penundaan Kewajiban Pembayaran Utang Pembicaraan Tingkat I/Pembahasan RUUKPKPU dilakukan antara DPR RI dan Komisi IX dengan Menteri Kehakiman dan Hak Asasi Manusia Republik Indonesia pada 21 September 2004. Pemerintah menyampaikan keterangannya sebagaimana yang tertuang dalam Surat Direktorat Jenderal Hukum dan Perundang-Undangan Departemen Kehakiman dan Hak Asasi Manusia Republik Indonesia (SK Ditjen Kumdang Depkeh dan HAM RI) Nomor I.UM.01.10-162 tentang Penyampaian Keterangan Pemerintah mengenai RUUKPKPU. Pembicaraan tingkat II/Pengambilan keputusan atas RUUKPKPU disampaikan dalam Rapat Paripurna DPRI pada tanggal 22 September 2004 setelah melalui berbagai pembahasan di tingkat rapat komisi, rapat-rapat kerja, rapat dengan 
pendapat umum, rapat-rapat panja dan rapatrapat tim perumus. Persetujuan DPR RI terhadap RUUKPKPU menjadi undang-undang tertuang dalam Surat Keputusan DPR RI Nomor: 09/DPR RI/I/2004-2005 tentang Persetujuan DPR RI terhadap RUUKPKPU.

Dalam pembahasan ketentuan Pasal 2 ayat (1) RUUKPKPU di Dewan Perwakilan Rakyat beberapa fraksi pernah mempersoalkan tentang tidak diaturnya ketentuan minimal jumlah utang sebagai syarat mengajukan permohonan pailit meskipun secara tersirat. Dalam pendapat akhir Fraksi Kebangkitan Bangsa terhadap RUUKPKPU disampaikan bahwa munculnya RUUKPKPU ini merupakan refleksi dari kesadaran bersama bahwa produk hukum dan/atau perundangundangan tentang kepailitan yang telah ada sebelumnya belum mampu memberikan kepastian hukum atas penyelesaian sengketa antara pihak debitor dan kreditor, khususnya dalam hal penyelesaian utang piutang. Perpu Nomor 1 Tahun 1998 yang kemudian ditetapkan menjadi Undang-Undang Nomor 4 Tahun 1998 yang mengatur kepailitan oleh banyak kalangan dinilai memiliki kelemahan terutama dalam hal begitu mudah dan sederhananya pihak debitor dapat dipailitkan dengan keputusan pengadilan (niaga) atas gugatan pihak kreditor tanpa melihat dan meneliti lebih dalam terhadap kemampuan dan/atau kinerja yang dimiliki oleh kreditor. Dalam sudut pandang ekonomi, sebuah perusahaan hanya dapat dinyatakan pailit (bankrupt) apabila nilai kewajibannya (debt) jauh melebihi nilai aset-asetnya. Namun apabila nilai aset perusahaan lebih besar dari kewajibannnya maka sebenarnya pihak pengadilan dapat menginstruksikan perusahaan untuk membayar kewajibannya, dan bukan langsung mempailitkannya. Dalam kasus PT Asuransi
Jiwa Manulife Indonesia (PT AJMI) dan PT Prudential Life Assurance (PT PLA), misalnya, seharusnya pihak pengadilan niaga dapat melakukan sebagaimana hal tersebut di atas. Karena, ketika dinyatakan pailit keduanya dalam kondisi sehat. PT AJMI memiliki total kekayaan Rp. 1,812 triliun dengan jumlah kewajiban 1,596 milyar, dengan tingkat Risk Based Capital (RBC) sebesar 167,26\%, sedangkan PT PLA total kekayaannya Rp. 1,575 triliun dengan jumlah kewajiban $\mathrm{Rp}$ 1,373 milyar, dengan tingkat RBC sebesar $225 \%$. Tingkat RBC keduanya jauh di atas ketentuan yang ditetapkan oleh Kementerian Keuangan sebesar $100 \% .{ }^{10}$ Berdasarkan pendapat dari tersebut diatas, salah satu fraksi dalam pembahasan terhadap RUUKPKPU sebenarnya secara tersirat dapat dimaknai tentang perlu dicantumkannya minimal jumlah utang dalam syarat kepailitan. Debitor yang sebenarnya mempunyai kemampuan membayar utang mendasarkan pada ketentuan Pasal 2 ayat (1) UUKPKPU dapat dipailitkan hanya karena utang yang jumlahnya sangat kecil.

\section{c. Ketentuan Pasal 2 Ayat (1) menu- rut UUKPKPU}

RUUKPKPU mendapat persetujuan oleh DPR RI pada 22 September 2004 dengan dikeluarkannya Surat Keputusan DPR RI Nomor: 09/DPR RI/I/ 2004-2005 terhadap RUUKPKPU. UUKPKPU mulai berlaku pada tanggal 18 Oktober 2004 yaitu pada saat undang-undang ini diundangkan ${ }^{11}$ dan diundangkan dalam Lembaran Negara Republik Indonesia (LNRI). ${ }^{12}$ Dengan diberlakukan undang-undang ini maka membatalkan berlakunya Peraturan Kepailitan dan UUK. ${ }^{13}$ Undang-Undang ini terdiri dari lima bab dengan 308 pasal. Beberapa bab terbagi menjadi bagian-bagian dan seterusnya terbagi lagi

10 Fraksi Kebangkitan Bangsa, "Pendapat Akhir Fraksi Kebangkitan Bangsa terhadap RUU KPKPU”, dalam Dewan Perwakilan Rakyat Republik Indonesia (DPR RI), 2004, Pendapat Akhir Bangsa terhadap RUUKPKPU, DPR RI, Jakarta, hlm. 4.

11 Pasal 308 Undang-Undang yang dimaksud disini adalah Undang-Undang Nomor 37 Tahun 2004 tentang Kepailitan dan Penundaan Kewajiban Pembayaran Utang (Lembaran Negara Republik Indonesia Tahun 2004 Nomor 131).

12 Undang-Undang yang dimaksud disini adalah Undang-Undang Nomor 37 Tahun 2004 tentang Kepailitan dan Penundaan Kewajiban Pembayaran Utang (Lembaran Negara Republik Indonesia Tahun 2004 Nomor 131).

13 Pasal 307 Undang-Undang yang dimaksud disini adalah Undang-Undang Nomor 37 Tahun 2004 tentang Kepailitan dan Penundaan Kewajiban Pembayaran Utang (Lembaran Negara Republik Indonesia Tahun 2004 Nomor 131). 
ke dalam paragraf-paragraf. Bab I mengatur tentang ketentuan umum, yang terdiri dari satu pasal yang berisi pengertian-pengertian umum beberapa istilah yang terdapat dalam Undang-Undang, Bab II berisi ketentuan tentang kepailitan. Bab III mengatur hal-hal yang berkaitan PKPU. Bab IV mengandungi ketentuan yang berisi tentang Permohonan Peninjauan Kembali dan Bab V berisi tentang ketentuan Lain-lain. Hal baru yang disempurnakan oleh UUKPKPU ini diantaranya adalah ketentuan tentang pengertian kepailitan, kreditur, debitur, debitur pailit, kurator dan hakim pengawas. Pengaturan yang paling menonjol dalam penyempurnaan undangundang ini adalah diintrodusirnya pengertian utang dan tempo utang dapat dituntut. ${ }^{14}$

Berkaitan dengan ketentuan Pasal 2, khususnya Pasal 2 ayat (1) antara RUUKPKPU dengan UUKPKPU secara substansial tidak ada perubahan mendasar. Hanya saja ada sedikit perubahan pada judul sub bagian dari naskah RUUKPKPU dengan UUKPKPU. Dalam Bab II tentang Kepailitan, bagian satu yang berjudul Putusan Pailit Pasal 2 RUUKPKPU disebutkan sebagai berikut:

(1) Debitor yang mempunyai dua atau lebih kreditor dan tidak membayar lunas sedikitnya satu utang yang telah jatuh waktu dan dapat ditagih, dinyatakan pailit dengan putusan Pengadilan, baik atas permohonannya sendiri maupun atas permohonan satu atau lebih kreditornya.

(2) Permohonan sebagaimana dimaksud pada ayat (1) dapat juga diajukan oleh kejaksaan untuk kepentingan umum.

(3) Dalam hal debitor adalah bank, permohonan pernyataan pailit hanya dapat diajukan oleh Bank Indonesia.

(4) Dalam hal debitor adalah perusahaan efek, bursa efek, lembaga kliring dan penjaminan, lembaga penyimpanan dan penyelesaian, permohonan pernyataan pailit hanya dapat diajukan oleh Badan Pengawas Pasar Modal.

(5) Dalam hal debitor adalah perusahaan asuransi, perusahaan reasuran- si, dana pensiun, atau Badan Usaha Milik Negara yang bergerak di bidang kepentingan publik, permohonan pernyataan pailit hanya dapat diajukan oleh Menteri Keuangan.

Dalam UUKPKPU judul sub bagian ini ditambahkan judul sub bagian kesatu menjadi "syarat dan putusan pailit", sehingga redaksinya dalam Bab II tentang Kepailitan Bagian Kesatu tentang Syarat Kepailitan Pasal 2 UUKPKPU adalah sebagai berikut:

(1) Debitor yang mempunyai dua atau lebih Kreditor dan tidak membayar lunas sedikitnya satu utang yang telah jatuh waktu dan dapat ditagih, dinyatakan pailit dengan putusan Pengadilan, baik atas permohonannya sendiri maupun atas permohonan satu atau lebih kreditornya.

(2) Permohonan sebagaimana dimaksud pada ayat (1) dapat juga diajukan oleh kejaksaan untuk kepentingan umum.

(3) Dalam hal Debitor adalah bank, permohonan pernyataan pailit hanya dapat diajukan oleh Bank Indonesia.

(4) Dalam hal Debitor adalah Perusahaan Efek, Bursa Efek, Lembaga Kliring dan Penjaminan, Lembaga Penyimpanan dan Penyelesaian, permohonan pernyataan pailit hanya dapat diajukan oleh Badan Pengawas Pasar Modal.

(5) Dalam hal debitor adalah perusahaan asuransi, perusahaan reasuransi, dana pensiun, atau Badan Usaha Milik Negara yang bergerak di bidang kepentingan publik, permohonan pernyataan pailit hanya dapat diajukan oleh Menteri Keuangan.

Berdasarkan konsep dalam draft RUUKPKPU, pembahasan RUUKPKPU di DPR RI maupun dalam UUKPKPU dapat disimpulkan bahwa berkaitan dengan syarat kepailitan sebagaimana diatur dalam Pasal 2 ayat (1) memang sejak awal tidak didisain untuk mengatur mengenai jumlah minimal utang untuk dapat dipailitkan.

2. Tidak Diaturnya Minimal Jumlah Utang Dalam Pasal 2 Ayat (1) UUKPKPU

14 Pasal 1 Undang-Undang yang dimaksud disini adalah Undang-Undang Nomor 37 Tahun 2004 tentang Kepailitan dan Penundaan Kewajiban Pembayaran Utang (Lembaran Negara Republik Indonesia Tahun 2004 Nomor 131). 
Berdasarkan konsep dalam draf RUUKPKPU, pembahasan RUUKPKPU di DPR RI maupun dalam UUKPKPU dapat disimpulkan bahwa berkaitan dengan syarat kepailitan sebagaimana diatur dalam Pasal 2 ayat (1) memang sejak awal tidak didisain untuk mengatur mengenai jumlah minimal utang untuk dapat dipailitkan. Dalam ketentuan Pasal 2 ayat (1) UUKPKPU, syarat untuk dapat dipailitkan yaitu debitur mempunyai dua atau lebih kreditur dan tidak membayar lunas minimum satu utang yang cukup waktu dan utangnya dapat ditagih. ${ }^{15}$ Berdasarkan ketentuan tersebut dapat dirumuskan adanya tiga hal untuk dapat dipailitkan, yaitu: (1) harus ada utang; (2) salah satu dari utang telah cukup waktu dan dapat ditagih; dan (3) debitur mempunyai sekurang-kurangnya dua atau lebih kreditur. ${ }^{16}$

UUKPKPU menerjemahkan utang sebagai kewajiban yang harus dibayarkan atau dapat dibayarkan dalam jumlah uang, baik itu dalam mata uang Indonesia ataupun mata uang asing, baik secara langsung ataupun yang ada pada waktu yang akan datang, yang timbul karena perjanjian utang piutang ataupun berdasarkan ketentuan yang diatur dalam undang-undang dan yang wajib dibayar oleh debitur dan sekiranya tidak dibayarkan memberikan hak kepada kreditur untuk menuntutnya dari harta debitur. ${ }^{17}$

Diaturnya ketentuan tentang pengertian utang ini dalam ketentuan UUKPKPU karena dalam ketentuan-ketentuan undang-undang kepailitan yang sebelumnya tidak terdapat ketentuan yang mengatur penafsiran utang ini. Oleh karena itu, antara pengadilan yang satu dengan yang lain me- nerjemahkan utang dalam pengertian yang berbeda. Dalam perkara Jeff Mustoffa Atmaja melawan. PT Profilindo Intratama Finance, ${ }^{18}$ pengadilan niaga menterjemahkan utang dalam pengertian yang luas, yaitu setiap tuntutan kreditur yang wujud sebagai pembayaran yang timbul karena adanya perjanjian utang-piutang, ${ }^{19}$ sedangkan Mahkamah Agung (MA) dalam putusan permohonan kasasi dalam perkara yang sama menterjemahkan utang dalam pengertian yang sempit, yaitu utang yang timbul dari perjanjian utang piutang, yaitu utang pokok dan bunganya. ${ }^{20}$ Kemudian MA dalam putusan permohonan peninjauan kembali (PK) yang juga dalam perkara yang sama memberikan pengertian utang dalam pengertian yang luas sebagaimana penerjemahan utang dalam putusan pengadilan niaga. ${ }^{21}$

Syarat kedua untuk dapat dipailitkan yaitu salah satu utang telah jatuh tempo dan harus dibayar. Utang yang telah jatuh tempo ini maksudnya adalah utang yang jangka waktu pembayarannya telah ditentukan dalam perjanjian utang. Utang yang telah jatuh tempo sebagaimana yang telah ditentukan dalam perjanjian utang ini adalah utang yang seharusnya dibayarkan. Dalam putusan permohonan peninjauan kembali perkara PT Asnawi Agung Corporation melawan tim likuidasi PT Astria Raya Bank, ${ }^{22}$ MA memutuskan bahwa syarat untuk dipailitkan telah diatur secara tegas dalam Pasal 1 UUK. Menurut ketentuan pasal ini, syarat untuk dipailitkan tidak bergantung kepada apakah debitur mampu membayar utang-utangnya tetapi bergantung kepada apakah debitur telah berusaha membayar utangnya yang telah jatuh tempo untuk dibayar dan tergantung juga kepada syarat apakah

15 Pasal 2 ayat (1) Undang-Undang yang dimaksud disini adalah Undang-Undang Nomor 37 Tahun 2004 tentang Kepailitan dan Penundaan Kewajiban Pembayaran Utang (Lembaran Negara Republik Indonesia Tahun 2004 Nomor 131).

16 Fanny Kurniawan, 2004, Penerapan Hak Jaminan dalam Kepailitan, Tugas Hukum Kepailitan, Fakultas Hukum Universitas Gadjah Mada, Yogyakarta, hlm. 24.

17 Pasal 1 angka 6 Undang-Undang Nomor 37 Tahun 2004 tentang Kepailitan dan Penundaan Kewajiban Pembayaran Utang (Lembaran Negara Republik Indonesia Tahun 2004 Nomor 131).

18 Putusan Pengadilan Niaga Jakarta Pusat Nomor 18/Pailit/1999/PN. Niaga. Jkt.Pst.

19 Lihat juga perkara Drs Husein Sani, et al melawan PT Modernland Realty Ltd. Putusan Pengadilan Niaga Nomor 7/Pailit/1998/PN Niaga/Jkt. Pst; perkara Hasim Sutiono et al. melawan PT Kutai Kartanegara Prima Coal et al. [Putusan Pengadilan Niaga Jakarta Pusat Nomor 18/ Pailit/1998/PN.Niaga.Jkt.Pst.]; perkara Sumeini Omar Sandjaya et al. melawan PT Jawa Barat Indah [Putusan Pengadilan Niaga Jakarta Pusat Nomor 27/Pailit/1998/PN.Niaga.Jkt.Pst.]; perkara PT Mustika Ratubuana International melawan Decky Tambayaong [Putusan Pe-ngadilan Niaga Jakarta Pusat Nomor 28/Pailit/1998/PN.Niaga.Jkt.Pst]; perkara Chinatrust Commercial Bank melawan PT Rajawali Nusantara Indonesia (Persero) [Putusan Pengadilan Niaga Jakarta Pusat Nomor 27/Pailit/1999/PN.Niaga.Jkt.Pst.]; perkara PT Supreme Cable Manufacturing Corporation Tbk. melawan PT Bank Sumitomo Niaga [Putusan Pengadilan Niaga Jakarta Pusat Nomor 28/Pailit/1999/PN.Niaga.Jkt.Pst.]; perkara Rodney Alexander Bothwell melawan PT WRS Indonesia [Putusan Pengadilan Niaga Jakarta Pusat Nomor 77/Pailit/2000/PN. Niaga. Jkt.Pst.].

20 Jeff Mustoffa Atmaja melawan PT Profilindo Intratama Finance [Putusan Mahkamah Agung RI Nomor 10K/N/98].

21 Jeff Mustoffa Atmaja melawan PT Profilindo Intratama Finance [Putusan Mahkamah Agung RI Nomor 14/PK/N/99].

22 Putusan Mahkamah Agung Republik Indonesia Nomor 18/PK/N/2000. 
ia mempunyai lebih daripada seorang kreditur.

Syarat paling akhir untuk dapat dipailitkan ke pengadilan niaga adalah debitur mempunyai minimum dua atau lebih kreditur. ${ }^{23}$ Kreditur adalah orang yang mempunyai tagihan utang berdasarkan perjanjian utang atau ketentuan Undang-Undang dan utangnya itu dapat dituntut di pengadilan. ${ }^{24}$ Dalam putusan permohonan kasasi dalam perkara PT Liman International Bank melawan PT Wahana Pandugraha, ${ }^{25}$ MA memutuskan bahwa kantor pajak dan kantor pajak bumi dan bangunan tidak termasuk dalam kategori sebagai kreditur dalam kepailitan. Utang pajak adalah tuntutan yang timbul berdasarkan Undang-Undang Nomor 6 Tahun $1983,{ }^{26}$ dan Undang-Undang Nomor 9 Tahun 1994. ${ }^{27}$ Kedua perundangan tersebut memberi kewenangan khusus kepada pegawai pajak melaksanakan tuntutan langsung terhadap utang pajak di luar campur tangan pengadilan niaga. Oleh karena itu, tuntutan yang berkaitan utang pajak penyelesaiannya tidak termasuk dalam tata cara kepailitan di pengadilan niaga. ${ }^{28}$

Dalam UUKPKPU tidak terdapat ketentuan tentang syarat berapa minimum jumlah minimum. Ketentuan seperti ini seharusnya diatur dalam Undang-Undang karena tidak adanya pengaturan ini akan sangat merugikan debitur. Kreditur yang jumlah utangnya sedikit (kecil) dibandingkan dengan harta yang dimilikinya dan semestinya kreditur ini mampu membayar utang tersebut, karena tidak adanya ketentuan mengenai syarat minimum jumlah utang akan dapat dipailitkan ke pengadilan. Menurut UUKPKPU berapapun jumlah utang yang ada sekiranya syarat menurut Pasal 1 ayat
(1) telah dipenuhi, maka debitur dapat dipailitkan ke pengadilan. Kreditur dengan jumlah tuntutan utang yang relatif sedikit (kecil) dapat mengajukan permohonan pailit ke pengadilan terhadap kreditur yang sebenarnya mampu membayar utangnya dan mempunyai aset yang jauh berlipat ganda jumlahnya dibandingkan dengan utang yang harus dilunasi. ${ }^{29}$ Dalam perkara Lee Boon Siong melawan PT Prudential Life Assurance, ${ }^{30}$ debitur (PT Prudential) dimohonkan pailit oleh salah seorang agennya bernama Lee Boon Siong (kreditur) ke pengadilan dikarenakan debitur tidak membayar utang kreditur sejumlah 7,2 milyar rupiah, meskipun aset si debitur yang perusahaanya berdiri pada tahun 1848 ini sampai dengan 31 Desember 2003 hampir mencapai 3,6 trilyun rupiah. ${ }^{31}$

Berdasarkan uraian di atas dapat disimpulkan bahwa konsep awal pembentukan ketentuan tentang syarat kepailitan, baik ketentuan tentang syarat kepailitan sebagaimana yang diatur dalam UUK maupun dalam UUKPKPU hanya mendasarkan kepada ketidakmauan (unwilling) dalam membayar utang sesuai dengan perjanjian utang yang dibuat. Pemailitan debitur tidak mempertimbangkan tentang kemampuan (unable) debitor dalam membayar utangnya. Konsep ini memang berbeda dengan konsep kepailitan dalam common law system. Dalam sistem hukum ini konsep kepailitan selalu berkaitan dengan ketidakmampuan debitor dalam membayar utangnya. Sebagaimana definisi kepailitan yang menyebutkan bahwa: "Bankrupt is the state or condition of one who is unable to pay his debts as they are, or become due". ${ }^{32}$

\footnotetext{
23 Syarat tentang kewajiban adanya dua atau lebih debitur ini sering dikenali dengan concursus creditorium. Lihat Sutan Remi Syahdeni, 2002, Hukum Kepailitan-Memahami Faillissements Verordening jo. Undang-Undang Nomor 4 Tahun 1998, Pustaka Utama Graffiti, Jakarta, hlm. 64.

24 Ibid. Pasal 1 angka 2 Undang-Undang Nomor 37 Tahun 2004 tentang Kepailitan dan Penundaan Kewajiban Pembayaran Utang (Lembaran Negara Republik Indonesia Tahun 2004 Nomor 131).

Putusan Mahkamah Agung Republik Indonesia Nomor 15 K/N/1999.

Undang-Undang tentang Ketentuan-Ketentuan Umum dan Tata Cara Perpajakan.

Undang-Undang tentang Amandemen atas Undang-Undang Nomor 6 Tahun 1983 tentang Ketentuan-Ketentuan Umum dan Tata Cara Perpajakan.

28 Lihat juga perkara PT Bank Niaga Tbk. melawan PT. Dharmala Agrifood Tbk [Putusan MA RI Nomor 7 K/N/1998], perkara PT Bank Yakin Makmur (PT Bank Yama) melawan PT. Nassau Sports Indonesia Tbk. [Putusan MA RI Nomor 7 K/N/1999] dan perkara The Dai Chi Kangyo Bank melawan PT. Supreme Cable Manufacturing Corporation Tbk. (PT Sucaco Tbk) Tbk [Putusan MA RI Nomor 10 K/N/2000].

29 Sutan Remy Syahdeni, “Jumlah Minimum Hutang dalam Undang-Undang Kepailitan”, Suara Pembaharuan, 26 Oktober 1998.

30 Putusan Pengadilan Niaga Jakarta Pusat Nomor 13/Pailit/2004/PN. Niaga. Jkt. Pst.

31 Lihat juga perkara Nyonya Ng Sok Hia melawan PT Prudential Life Assurance [Putusan Pengadilan Niaga Jakarta Pusat Nomor 25/ Pailit/2004/PN. Niaga. Jkt. Pst] dan perkara Paul Sukran, S.H. melawan PT. Asuransi Jiwa Manulife Indonesia (AJMI) [Keputusan Pengadilan Niaga Jakarta Pusat Nomor 10/Pailit/2002/PN. Niaga. Jkt. Pst.].
} 
3. Perlu Diaturnya Minimal Jumlah Utang dalam Undang-Undang Kepailitan di Indonesia

Tidak adanya pengaturan tentang jumlah minimum utang sebagai syarat kepailitan sebagaimana diatur dalam Pasal 2 ayat (1) UUKPKPU ini di dalam praktek akan sangat merugikan debitur. Debitor dengan jumlah utang yang sangat sedikit (kecil) dibandingkan dengan kemampuan harta yang dimilikinya dan semestinya debitur ini mampu membayar utang tersebut, karena tidak adanya ketentuan mengenai syarat minimum jumlah utang akan dapat dipailitkan ke pengadilan. Menurut UUKPKPU, berapapun jumlah utang yang ada sekiranya syarat menurut Pasal 2 ayat (1) UUKPKPU telah dipenuhi, maka debitur dapat dipailitkan ke pengadilan. Debitur dengan jumlah tuntutan utang yang relatif sedikit (kecil) dapat mengajukan permohonan pailit ke pengadilan terhadap kreditur yang sebenarnya mampu membayar utangnya dan mempunyai aset yang jauh berlipat ganda jumlahnya dibandingkan dengan utang yang harus dilunaskan. ${ }^{33}$ Dalam beberapa kasus, tidak diaturnya minimal jumlah utang dalam ketentuan Pasal 2 ayat (1) ini telah mengakibatkan beberapa debitor mampu dipailitkan oleh pengadilan. Sebagai contoh PT Asuransi jiwa Manulife Indonesia (PT AJMI), PT Prudential Life Assurance (PT PLA) dan terakhir PT Telkomsel.

Sekedar menyandingkan pengaturan kepailitan, khususnya tentang syarat kepailitan ini dalam peraturan perundang-undangan kepailitan dalam sistem hukum negara lain. Pengaturan syarat kepailitan di beberapa negara mencantumkan syarat minimal jumlah utang dalam ketentuan peraturan perundang-undangan kepailitannya.

Dalam amandemen Undang-Undang Kepai- litan Malaysia 2003 diatur tentang minimal jumlah utang ini. Sekiranya kepailitan diajukan oleh kreditur, maka dia harus mengajukan permohonan ke pengadilan terhadap debitur, setelah debitur gagal memenuhi tuntutan sebagaimana yang disampaikan melalui pemberitahuan kepailitan yang telah diserahkan sebelumnya. Permohonan ini dapat diajukan ke pengadilan jika memenuhi syarat yaitu debitur tidak mampu membayar utangnya kepada kreditur. Jumlah utang tersebut harus: ${ }^{34}$ (1) berjumlah sekurang-kurangnya 30,000 ringgit Malaysia; ${ }^{35}$ (2) utang adalah untuk sejumlah yang dapat ditentukan (liquidated sum), yang perlu dibayar segera ataupun yang pada suatu waktu yang telah ditetapkan; (3) perbuatan kepailitan telah terjadi dalam waktu enam bulan sebelum permohonan kepailitan diajukan; dan (4) debitur harus berdomisili di Malaysia sekurang-kurangnya satu tahun sebelum permohonan kepailitan dimohonkan di pengadilan. ${ }^{36}$

Demikian juga contoh di beberapa negara lainnya, seperti di England $^{37}$, Australia ${ }^{38}$ dan Singapura ${ }^{39}$. Menurut undang-undang kepailitan di ketiga negara, terdapat pengaturan tentang ketentuan jumlah minimum utang. Di England, jumlah minimum utang yaitu sejumlah $£ 200,{ }^{40}$ di Australia $\$ 1,500,{ }^{41}$ sedangkan di Singapura, $\$ 10,000 .{ }^{42}$

\section{Kesimpulan}

Berdasarkan permasalahan dan hasil penelitian serta pembahasan sebagaimana yang telah diuraikan dalam bab-bab sebelumnya maka dapat disimpulkan bahwa: Pertama, ketentuan Pasal 2 ayat (1) UUKPKPU merumuskan syarat kepailitan sangat sederhana di mana syarat untuk dapat dipailitkan yaitu debitor yang mempunyai dua atau lebih kreditor dan tidak membayar lunas sedikitnya satu utang yang telah jatuh waktu dan dapat ditagih ka-

\footnotetext{
Henry Campbell Black, 1974, Black's Law Dictionary, West Publising Co., St. Paul Minnesota, hlm. 425.

Sutan Remy Syahdeni, "Jumlah Minimum Hutang dalam Undang-Undang Kepailitan, Suara Pembaharuan, 26 Oktober 1998.

Re Lee Boon Hooi [1992] 4 CLJ 1903.

Amandemen Undang-Undang Kepailitan Malaysia 2003.

Pasal 5 ayat (1) huruf a, b, c dan d. Amandemen Undang-Undang Kepailitan Malaysia 2003.

Ian F. Fletcher, 1978, Legal Topics Series: Law of Bankruptcy, Mac Donald and Evan. Ltd, Plymouth, hlm. 38-56. Lihat juga Steven A. Frieze, 1992, Handbook of Bankruptcy Law and Practice, Longman Group UK. Ltd, London, hlm. 27 dan hlm. 50.

38 Dennis Rose, 1994, Australian Bankruptcy Law, Tenth edition, Sydney, The Law Book Company Limited, Sydney, hlm. 2, hlm. 82 dan hlm. 33 .

39 Kala Anandarajah dkk., 1999, Law and Practice of Bankruptcy in Singapore and Malaysia, Butterworths Asia, Singapura, hlm. 71 dan hlm. 113.

Pasal 44 Bankruptcy Act of Australia 1966

Pasal 4 (1)(a) Insolvency Act of England 1986.

42 Pasal 61(1)(a) Bankruptcy Act of Singapore 1995
} 
rena dalam mempailitkan dasarnya adalah ketidakmauan (unwilling) debitor membayar utang dan bukan berdasarkan kepada ketidakmampuan (unable) debitor membayar utang; Kedua, ketentuan Pasal 2 ayat (1) UUKPKPU tidak mengatur mini- mal jumlah utang sebagai syarat untuk mengajukan permohonan pailit, dan Ketiga, kemampuan debitur dalam membayar utang perlu diatur dalam untuk menghindari debitur yang sebenarnya mampu dalam membayar utang.

\section{DAFTAR PUSTAKA}

\section{A. Buku}

Babbie, 1986, The Practice of Social Research, Wadsworth Publishing Co., California.

Black, Henry Campbell, 1974, Black's Law Dictionary, West Publising Co., St. Paul Minnesota.

Dennis, 1994, Australian Bankruptcy Law, Sydney, The Law Book Company Limited, Sydney.

Fraksi Kebangkitan Bangsa, 2004, Pendapat Akhir Fraksi Kebangkitan Bangsa terhadap RUU KPKPU, dalam Dewan Perwakilan Rakyat Republik Indonesia (DPR RI), Pendapat Akhir Bangsa terhadap RUUKPKPU, DPR RI, Jakarta.

Fletcher, Ian F., 1978, Legal Topics Series: Law of Bankruptcy, Mac Donald and Evan Ltd., Plymouth.

Frieze, Steven A., 1992, Handbook of Bankruptcy Law and Practice, Longman Group UK Ltd., London.

Kumar, Ranjit, 1999, Research Methodology: A Step-by-Step Guide for Beginners, Addison Wedley Longman Australia Pty. Limited, Melbourne.

Rose, Kala Anandarajah dkk., 1999, Law and practice of bankruptcy in Singapore and Malaysia, Butterworths Asia, Singapura.

Soemitro, Ronny Hanitijo, 1994, Metodologi Penelitian Hukum dan Jurimetri, Ghalia Indonesia, Jakarta.

Syahdeni, Sutan Remi, 2002, Hukum Kepailitan-Memahami Faillissements Verordening jo. Undang-Undang Nomor 4 Tahun 1998, Pustaka Utama Graffiti, Jakarta.

\section{B. Hasil Penelitian/Tugas Akhir}

Butar-Butar, Elisabeth Nurhaini, 2001, Relevansi Pengadilan Negeri/Niaga dalam Menyelesaikan Utang Piutang, Tesis, Program Pas- casarjana Fakultas Hukum Universitas Gadjah Mada, Yogyakarta.

Kurniawan, Fanny, 2004, Penerapan Hak Jaminan dalam Kepailitan, Tugas Akhir, Fakultas Hukum Universitas Gadjah Mada, Yogyakarta.

Wijayanta, Tata, 2003, Relevansi Lembaga Dissenting Opinion dalam Penyelesaian Sengketa Kepailitan di Pengadilan Niaga, Tesis, Program Pascasarjana Fakultas Hukum Universitas Gadjah Mada, Yogyakarta.

\section{Artikel Jurnal}

Johson, Simon, Peter Boone, Alasdair Breach, Eric Friedman, "Corporate Governance in the Asian Financial Crisis", Journal of Financial Economic, Vol. 58, No. 152.

Mitton, Todd, "A Cross-Firm Analysis ofthe Impact of Corporate Governance on the East Asian Financial Crisis", Journal of Financial Economic, Vol. 64, No. 215.

Radelet, S. dan J. Sachs, The Asset of the Asian Crisis, dalam Frederic S. Mishkin, "Lessons from the Asian Crisis", Journal of International Money and Finance, Vol. 18, No. 714.

\section{Artikel dalam Antologi dengan Editor}

Fraksi Kebangkitan Bangsa, "Pendapat Akhir Fraksi Kebangkitan Bangsa terhadap RUU KPKPU", dalam Dewan Perwakilan Rakyat Republik Indonesia (DPR RI), 2004, Pendapat Akhir Bangsa terhadap RUUKPKPU, DPR RI, Jakarta.

Kesowo, Bambang, "Perpu Nomor 1 Tahun 1998, Latar Belakang dan Arahnya", dalam A. Rudhy Lontoh, Denny Kailimang \& Benny Ponto [Ed.], 2001, Penyelesaian Utang Piutang Melalui Pailit atau Penundaan Kewajiban Pembayaran Utang, Alumni, Bandung. 


\section{E. Artikel Koran dan Majalah}

Syahdeni, Sutan Remy, "Jumlah Minimum Hutang dalam Undang-Undang Kepailitan”, Suara Pembaharuan, 26 Oktober 1998.

\section{F. Sumber Internet}

Chowdhry, Bhagwam dan Amit Goyal, "Under standing The Financial Crisis in Asia", http:// www.elsevier.com/locate/econbase, diakses 20 April 2008.

Jened, Rahmi, "Perlindungan Hukum Investor Pemegang Obligasi dalam Rangka Perjanjian Perwaliamanatan Bank di Pasar Modal", http://www.library@lib.unairac.id, diakses 15 September 2004.

\section{G. Peraturan Perundang-Undangan}

Undang-Undang Nomor 4 Tahun 1998 tentang Kepailitan (Lembaran Negara Republik Indonesia Tahun 1998 Nomor 7).

Undang-Undang Nomor 37 Tahun 2004 tentang Kepailitan dan Penundaan Kewajiban Pembayaran Utang (Lembaran Negara Repu-blik Indonesia Tahun 2004 Nomor 131).

Undang-Undang tentang Amandemen atas Undang-Undang Nomor 6 Tahun 1983 tentang Ketentuan-Ketentuan Umum dan Tata Cara Perpajakan.

Undang-Undang Kepailitan Malaysia 2003.

Insolvency Act of England 1986.

Bankruptcy Act of Australia 1966.

Bankruptcy Act of Singapore 1995.

\section{H. Putusan Pengadilan}

Putusan Pengadilan Niaga Jakarta Pusat No. 18/ Pailit/1999/PN.Niaga.Jkt.Pst.

Putusan Pengadilan Niaga No. 7/Pailit/1998/PN. Niaga/Jkt.Pst.

Putusan Pengadilan Niaga Jakarta Pusat No. 18/ Pailit/1998/PN.Niaga/Jkt.Pst.

Putusan Pengadilan Niaga Jakarta Pusat No. 27/ Pailit/1998/PN.Niaga./Jkt.Pst.

Putusan Pengadilan Niaga Jakarta Pusat No. 28/ Pailit/1998/PN.Niaga.Jkt.Pst.

Putusan Pengadilan Niaga Jakarta Pusat No. 27/ Pailit/1999/PN.Niaga.Jkt.Pst.

Putusan Pengadilan Niaga Jakarta Pusat No. 28/ Pailit/1999/PN.Niaga Jkt.Pst.

Putusan Pengadilan Niaga Jakarta Pusat No. 77/ Pailit/2000/PN.Niaga.Jkt.Pst.

Putusan Mahkamah Agung Republik Indonesia No. $18 / \mathrm{PK} / \mathrm{N} / 2000$.

Putusan Mahkamah Agung Republik Indonesia No. 15 K/N/1999.

Putusan Pengadilan Niaga Jakarta Pusat No. 13/ Pailit/2004/PN.Niaga.Jkt.Pst.

Putusan Pengadilan Niaga Jakarta Pusat No. 25/ Pailit/2004/PN.Niaga.Jkt.Pst.

Putusan Pengadilan Niaga Jakarta Pusat No. 10/ Pailit/2002/PN.Niaga.Jkt.Pst.

Putusan MA RI Nomor 7 K/N/1998.

Putusan MA RI Nomor 7 K/N/1999.

Putusan MA RI Nomor 10 K/N/2000. 